$\underline{\text { Book Review }}$

\title{
Social Studies for the Twenty-First Century
}

\section{"Social Studies for Secondary Schools: Teaching to Learn, Learning to Teach" by Alan J. Singer}

By Orel Beilinson

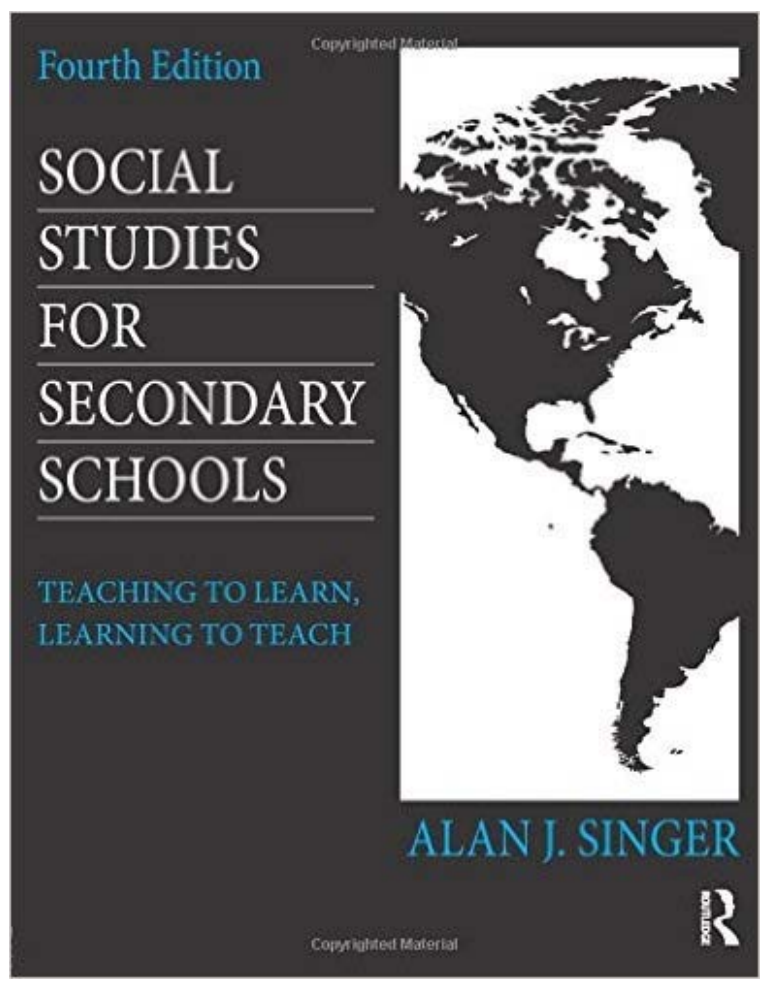

Accumulating in its pages over 30 years of experience in the classroom and in research, Social Studies for Secondary Schools is a masterpiece and true textbook for studentteachers and young teachers of social studies. It combines the standard "teacher education" textbook, mixing rich practice with some theoretical background based on a personal educational philosophy, with a "self-help guide" or "cookbook" - even at times a workbook - that seeks to give young teachers a platform through which they can mold their character as a social studies educator.

It is worth mentioning early on that Social Studies for Secondary Schools is written in the light of "democratic education" that follows "the traditions of Maxine Greene and J ohn Dewey" (8). In adopting this philosophical approach to education-one that is generally consistent with the way public (and private) education is heading - this text encourages building "democratic communities" in the classroom, calls for pluralism in opinions and a variety of experiences, and endorses active learning and critical engagement with the material, often blurring the line between academic study and personal exploration.

After the first chapter, which serves as a general introduction, the five subsequent chapters (chapters 2-6) are grouped under the title "Thinking about Social Studies." Chapter 2 focuses on history, introducing key concepts of historical thought and the historical profession in a way that can be (and should be) applied to the classroom, such as the nature of historical facts and the work of the historian. Chapter 3 offers a more holistic view of the social studies and social sciences, linking history, economics, and other disciplines, while emphasizing the integrative nature of the "bigger picture" that this subject matter provides. Chapter 4 assumes a more applied character, bridging the theoretical foundations and assumptions of 
social studies with the classroom for the first step of teaching: planning your goals. The following chapter discusses the "political" dimension of teaching social studies and beyond (in a manner that makes the title of this chapter misleading). Consequently, it brings to the floor such questions as "Should teachers discuss their opinions in class?" and "How can teachers empower students?" The last chapter in this section discusses curriculum planning.

The second section of Social Studies for Secondary Schools is about "preparing to teach social studies." While the last section of part one ended in curriculum planning, the first chapter of this section (chapter 7) takes the individual unit as its subject; the second chapter (chapter 8) subsequently covers the individual lesson. Finally, chapter 9 discusses activity-based lessons. Each chapter in this section, even more than the sections before it, is full of practical suggestions, full-length samples, and a lot of freedom, encouraging each teacher to develop his or her own ideas about teaching and different classroom practices.

The last four chapters are grouped as "implementingyour ideas." Chapter 10 discusses "controversy-centered, thematic, and interdisciplinary units." It is followed by a section focusing on project-based learning (PBL). Chapter 12 centers on assessment. The book's last chapter provides a thorough treatment of classroom resources, ranging from computers to movies to fair use of copyrighted materials. The discussion of computers in the learning process, however, should be updated as many more possibilities now exist, including Kahoot and Edmodo, while some sites mentioned in the chapter are no longer active.

Overall, this is an excellent starting point for new social studies teachers. With its emphasis on classroom practices grounded in theory, it is ideal for teachers still fashioning their identity as educators who seek guidance in developing healthy, learner-centered social studies classrooms. Its unique format, blending features of textbooks, cookbooks, and self-help guides, reflects the author's extensive experiences in the classroom and makes this book especially attractive for teacher training programs. However, it also works as a self-study book.

One striking omission in Social Studies for Secondary Schools is the "technological turn" in education. One would expect such a book to elaborate much more on the options available to educators made by recent technological advances, starting with "online activism" and culminating in "flipped lessons." Nevertheless, it is perhaps the only disappointment in over 400 pages of tips, tricks, and scholarly analysis of educational issues in social studies of the highest quality. Consequently, this omission does not significantly impede the overall quality of this volume.

\footnotetext{
"Social Studies for Secondary Schools: Teaching to Learn, Learning to Teach." 4th ed. By Alan J. Singer. New York: Routledge, 2015. ISBN: 978-0-415-82658-7
}

\begin{abstract}
About the Author
Alan J . Singer is professor of secondary education and coordinator of social studies education in the department of teaching, literacy, and leadership at Hofstra University.
\end{abstract}

\author{
About the Reviewer \\ Orel Beilinson is the principal and a lecturer of \\ history/ social studies at Harari College Worldwide.
}

